\title{
Allah Sebagai Bapa dan Ibu: Studi Komparatif Dari Konstruksi Allah sebagai Bapa dalam Injil Matius dan Allah sebagai Ibu dalam Teologi Feminis
}

\author{
Pelita Hati Surbakti \\ Email: Pelita_surbakti@yahoo.com
}

\begin{abstract}
Considering a product of androcentric culture that may perpetuate misogynists, some Christian feminist theologians reject the hegemony use of the word "Father" to call God. They insists that the notion of Mother is equally important and should be employed and prioritized to mention God's name. Unfortunately, this proposal was based on a less positive interpretation of the word Father in the Bible. This article will demonstrate that the title Father for God in the Gospel of Matthew does not contain any misogynistic motive. In fact,through comparative studies of the proper theology of Matthew's gospel and feminist theology, the two are basically based on the same socio-religious background and are against proper theology, which proclaims a transcendent and hierarchical portrait of God. Both emphasize an immanent God. Consequently, the notion of Mother applied to God should not be contrasted to of the title Father as the two are equally important.
\end{abstract}

Keywords: Father, Mother, Feminist, Gospel of Matthew, Proper Theology.

\begin{abstract}
Abstrak
Karena dinilai sebagai produk budaya androsentris yang dapat memunculkan misoginis, beberapa teolog feminis Kristen menolak hegemoni penggunaan kata "Bapa" sebagai sebutan bagi Allah. Mereka menilai bahwa Ibu juga layak, bahkan seharusnya diutamakan, untuk menyapa Allah. Sayangnya usulan ini tampaknya lahir dari pemaknaan yang kurang positif pada kata Bapa dalam Alkitab. Melalui tulisan ini, saya membuktikan bahwa sebutan Bapa kepada Allah dalam injil Matius sama sekali tidak memuat nuansa misoginis. Sebaliknya, melalui studi komparatif, konstruksi teologi proper injil Matius dan teologi feminis sebenarnya didasari oleh latar sosio-religius yang sama yaitu tengah melawan teologi proper yang memproklamasikan potret Allah yang transenden serta hierarkis. Keduanya menekankan
\end{abstract}


Allah yang imanen. Dengan kesamaan ini, Allah sebagai Ibu seharusnya bukanlah antitesis dari Allah sebagai Bapa, namun keduanya bersifat komplementer.

Kata kunci: Bapa, Ibu, Feminis, Injil Matius, Teologi Proper.

\section{Pendahuluan}

Secara praktis, sebutan yang paling sering dipakai untuk memanggil Allah dalam kekristenan adalah Bapa. Bila dilihat dalam doa-doa yang diucapkan dan dalam syair lagulagu rohani yang populer yang sangat disukai oleh jemaat, orang Kristen sangat gemar menyapa Allahnya sebagai Bapa. Barth menyatakan, "The obedience of Christian follows from the fact that in Jesus Christ they may recognize God as his Father and theirs, and themselves as his children."1 Pada sisi yang lain penggunaan sebutan Bapa bagi Allah kerap menjadi sorotan dalam teologi feminis Kristen (selanjutnya disebut teologi feminis). Sebutan tersebut dianggap lahir dari kultur androsentris yang pada gilirannya telah menyebabkan diskriminasi bagi kaum perempuan. ${ }^{2}$ Karenanya teolog feminis mencoba mengusulkan bingkai baru dalam membaca teks-teks Alkitab mengenai Allah. Salah satu hasil pembacaan teks dengan bingkai baru ini adalah mengusulkan penyebutan Allah bukan saja sebagai Bapa namun juga sebagai Ibu.

Although Jesus Christ taught his followers to address God as "Father" in the Lord's Paryer, during the last forty years, feminism has vigorously raised the charge that this term can no longer efectively serve Christians ... Instead, it has maintained that feminine names and terms of reference also need to be used. In particularly, "Mother" has become a frequent term used in place of or alongside "Father". 3

Sebutan Allah sebagai Ibu memang memungkinkan, ${ }^{4}$ namun yang menjadi perhatian dalam tulisan ini adalah pada konstruksi makna kata "Bapa" yang tidak positif di kalangan "beberapa" teolog feminis yang akhirnya menolak hegemoni penggunaan kata tersebut untuk memanggil Allah. Surburg mengakui adanya penolakan tersebut dengan menyatakan, "Reformist feminists raise two objections to the use of 'Father'."

49.

${ }^{1}$ Karl Barth, The Christian Life: Church Dogmatics Vol. IV, part 4 (Grand Rapids: Eerdmans, 1981),

2 Baca Mary Daly, Beyond God the Father: Toward a Philosophy of Women's Liberation (Boston: Beacon, 1974), 13-43.

${ }^{3}$ Mark P. Surburg, "God Our Mother? Biblical and Philosophical Considerations in Feminist God Language", Concordia Theological Quarterly, Vol. 79 (2015), 49.

${ }^{4}$ Baca Elizabeth A. Johnson, She Who Is: The Mystery of God in Feminist Theological Discourse (New York: Crossroad, 1994), 170-187. Dalam bagian ini Johnson menyajikan sejumlah data biblis yang menggambarkan Allah yang tidak saja melahirkan namun juga merawat umat-Nya laksana seorang Ibu (Bdk. Ul. 32:18; Ayb. 38:29).

${ }^{5}$ Surburg, "God Our Mother?", 50. 
Sayangnya, pada saat yang sama, teologi mengenai Allah (teologi proper) memang kurang mendapat perhatian dari para ahli Perjanjian Baru. ${ }^{6}$ Realitas ini membuat minimnya studi tentang Allah sebagai Bapa dalam injil Matius pun menjadi beralasan. Melalui tulisan ini saya hendak memperlihatkan bahwa konsep Allah sebagai Bapa dalam injil Matius, ${ }^{7}$ sama sekali tidak sejalan dengan penindasan dan diskriminasi, termasuk kepada perempuan. Bila dalam kenyataannya penyebutan Allah sebagai Bapa dianggap lahir dari kultur androsentris dan selanjutnya menjadi "salah satu" penyebab terjadinya penindasan, atau setidaknya melanggengkan penindasan, maka pemaknaan sebutan "Bapa" semacam itu tidak memiliki dasar biblis yang memadai. Tulisan ini akan memberikan pemahaman yang dimaksud. Dengan pemahaman tersebut diharapkan akan ditemukan titik temu antara latar sejarah penyebutan Allah sebagai Bapa dalam Injil Matius dan latar sejarah konstruksi teologi proper Feminis. Dengan titik temu ini sebutan Ibu atau Bapa bagi Allah tidak lagi berada pada posisi antetesis tetapi pada posisi saling melengkapi.

\section{Metode Penelitian}

Penelitian ini merupakan penelitian kualitatif melalui studi kepustakaan. Dalam studi kepustakaan ini penulis akan menggunakan studi komparatif yaitu membandingkan dua konstruksi bagian dari teologi proper injil Matius dan teologi feminis. Teologi proper yang dimaksud dibatasi pada gagasan sebutan Bapa bagi Allah. Pendekatan yang dilakukan pada kedua teologi yang dimaksud adalah dengan melakukan rekonstruksi latar sejarah keduanya untuk melihat latar sosial yang menjadi konteks lahirnya kedua teologi yang dimaksud.

\section{Allah dalam Studi Perjanjian Baru}

Berdasarkan tulisan Dahl, ${ }^{8}$ guru besar di Yale Divinity School, yang dikutip oleh Thompson, tampak adanya kesadaran akan pengabaian terhadap konsep tentang Allah (teologi proper) dalam injil, bahkan dalam keseluruhan $\mathrm{PB}$, sejak empat dekade yang lalu. Terhadap tulisan Dahl tersebut Thompson menyatakan, "That neglected factor, according to Dahl, was God." 9 Thompson menambahkan bahwa kesimpulan Dahl tersebut dipertegas oleh Keck. ${ }^{10}$ Thompson menyatakan,

${ }^{6}$ Nils A. Dahl, "The Neglected Factor in New Testament Theology,” dalam Donald H. Juel (ed.), Jesus the Christ: The Historical Origins of Christological Doctrin (Minneapolis: Fortress, 1991), 153-163; Marrianne Meye Thompson, The God of the Gospel of John (Grand Rapids: Eerrmans, 2001), 1; Leander Keck, "Toward the Renewal of New Testament Chrsistology," NTS 32 (1986): 362-377; Benedict Thomas Viviano, "God in the Gospel According to Mathhew," Interpretation, Vol. 64/4 (October 2010), 342.

${ }^{7}$ Kata Bapa (patēr) sebagai sebutan kepada Allah muncul sebanyak 43 kali. Jumlah ini mendekati jumlah kata Allah (Theos) yang muncul sebanyak 51 kali.

${ }^{8}$ Dahl, "The Neglected Factor in New Testament Theology," 5-8.

${ }^{9}$ Marrianne Meye Thompson, The God of the Gospel of John (Grand Rapids: Eerrmans, 2001), 1.

${ }^{10}$ Keck, "Toward the Renewal of New Testament Chrsistology," 362-377. 
A decade later Leander Keck asserted that Dahl was indeed correct: "The understanding of God has been neglected factor in the study of New Testament theology as a whole. This is particularly true of the study of New Testament christology, even though every statement about Christ implicated God, begining with the designation of Jesus as the Anointed."11

Seakan hendak menyimpulkan hasil pengamatannya, Thompson menyatakan, "While there are numerous studies about God in the OT, focused variously on names for God or conceptions of God, 'God' has already been ignored as the proper subject of inquiry and reflection with respect to the substance of NT theology."12 Sekitar satu dekade setelah Thompson atau lebih dari tiga dekade setelah Dahl, Benedict Thomas Viviano masih menemukan pengabaian itu. Dalam konteks injil Matius, Viviano menyatakan, "Yet up still now, the focus in research has been on Christology, eschatology, ethics, or ecclesiology in Matthew. This gospel is not known for special redactional viewpoint about God."13 Bila kita melihat kesimpulan Jeremias terhadap penyebutan Allah sebagai Bapa dalam injil Matius misalnya, ${ }^{14}$ benarlah kesimpulan Viviano di atas sebab sebutan Bapa kepada Allah sekalipun ternyata dibaca secara kristologis. Karena realitas ini, tidak mengherankan bila pemahaman penggunaan sebuatan Allah sebagai Bapa, khususnya dalam injil Matius, masih kurang mendalam.

\section{Allah sebagai Bapa dalam Pandangan Teolog Feminis}

Kajian serta kesimpulan mengenai Allah dalam teologi feminis sangat beragam. Kali ini saya menyoroti adanya resistensi terhadap penggunaan sebutan Bapa bagi Allah dalam konstruksi teologi proper teologi feminis. Berdasarkan kutipan dari beberapa tulisan berikut, resistensi semacam itu lahir dari sebuah persepsi yang kurang positif, terhadap penggunaan sebutan Bapa bagi Allah. Daly misalnya menyatakan,

The symbol of the Father God, spawned in the human imagination and sustained as plausible by patriarchy, has in turn rendered service to this type of society by making its mechanisms for the oppression of women appear right and fitting... Within this context a mystification of roles takes place: the husband dominating his wife represents God 'himself'."15

Hal yang sama masih tampak dalam tulisan Watson, sekitar tiga dasawarsa setelah pernyataan Daly di atas. Persis setelah membuat sebuah kesimpulan bahwa bahasa laki-laki (male

11 Thompson, The God of the Gospel of John, 1.

12 Ibid., 1.

13 Benedict Thomas Viviano, "God in the Gospel According to Mathhew," Interpretation, vol. 64/4 (October 2010), 342.

14 "When Jesus spoke of God as 'my father' he was reffering not to a familiarity and intimacy with God available to anyone, but to unique revelation which was bestowed upon him." Joachim Jeremias, The Central Message of the New Testament (New York: Charles's Sons, 1965), 26-27.

${ }^{15}$ Daly, Beyond God the Father, 13. 
language) yang dialamatkan kepada Allah adalah sebagai pembenaran atas marjinalisasi, pelecehan, serta penindasan kepada kaum perempuan, ${ }^{16}$ dia mengutip pertanyaan retorik Sölle yaitu, "Can the word 'father' still mean 'God' when we have learned that God and liberation are mutually inclusive concepts?"17 Gambaran ini memperlihatkan bahwa sebutan Bapa bagi Allah seolah-olah tidak tepat sebab Allah identik dengan pembebasan sedangkan kata "bapa" identik dengan pembelengguan. Kesimpulan di atas tidak bermaksud menyamaratakan seluruh pandangan teolog feminis, namun pandangan seperti ini memang ada.

\section{Latar Historis Teologi Feminis}

Walaupun berbagai gerakan semacam gerakan feminis yang kita kenal saat ini telah ada sejak lama, istilah "feminis" sendiri - sebagai sebuah gerakan pembebasan - digunakan pertama kali oleh Auclert pada tahun 1882. ${ }^{18}$ Gerakan feminis yang digulirkan oleh Auclert pada zamannya adalah untuk memperjuangkan hak-hak politik perempuan. Gerakan ini umumnya merupakan upaya untuk menentang diskriminasi (terhadap kaum perempuan). Pada dasarnya perumusan ulang teologi proper dari kelompok feminis adalah karena teologi proper klasik Barat (selanjutnya disebut "teologi klasik") dinilai memiliki ekses yang sangat serius bagi kaum perempuan. Setidaknya teologi klasik dipandang tidak mampu untuk membendung gelombang berbagai tindakan yang diskriminatif terhadap kaum perempuan, bahkan terkesan melanggengkannya. Teologi klasik, yang cenderung dinilai sebagai pengalaman religius kaum laki-laki, dianggap tidak memberi ruang bagi pengalaman religius perempuan. ${ }^{19}$

Secara umum ada dua tipe gerakan feminis yakni apa yang dia sebut sebagai "teologi feminis revolusioner" dan "teologi feminis reformis." ${ }^{20}$ Jenis yang pertama merupakan teologi ekstrim dan justru lebih terkesan sebagai sebuah perlawanan terhadap hegemoni kultur lakilaki yang membabi buta. Teologi ini bahkan mendorong orang untuk menarik diri dari gereja, tidak tertarik kepada refleksi mengenai Yesus Kristus, dan menyebut Allah antara lain dengan sebutan Dewi. ${ }^{21}$ Mereka juga cenderung menolak Alkitab karena dinilai terlalu androsentris yang mendukung misoginis. ${ }^{22}$ Sementara jenis yang kedua lebih kepada sebuah upaya pembaharuan (reformasi). Gagasan utamanya adalah keseimbangan dan kesetaraan demi menghapus segala tindakan diskriminatif dan penindasan. Karena itu pusat perhatian tokoh-

16 "Feminist theologians understand their critique of exclusively male-God language as inseparable from a critical analysis of its use as a means of justifying and enforcing the marginalization, abuse, and oppression of women.” Natalie K. Watson, Feminist Theology (Grand Rapids: Eerdmans, 2003), 29.

17 Ibid., 29. 2002), 17.

${ }^{18}$ Anne M. Clifford, Memperkenalkan Teologi Feminis, terj. Yosef M. Florisan (Maumere: Ledalero,

19 "The use of women's experience in feminist theology, therefore, explodes as critical force, exposing classical theology, including codified traditions, as a base of male experience rather than on universal human experience." Rosemary Radford Ruether, Sexism and God Talk: Toward a Feminist Theology (Boston: Beacon Press, 1983), 13.

20 Elizabeth A. Johnson, Kristologi di Mata Kaum Feminis, terj. A. Widyamartaya (Yogyakarta: Kanisius, 2003), 120.

${ }^{21}$ Ibid., 121.

${ }^{22}$ Clifford, Memperkenalkan Teologi Feminis, 91. 
tokoh gerakan feminis jenis ini tidak saja kaum perempuan namun semua orang yang mengalami diskriminasi dan penindasan. ${ }^{23}$ Kalaupun gerakan ini tampak menentang hegemoni nuansa laki-laki, hal itu dikarenakan adanya ketidakseimbangan. Kelompok ini tidak menolak Alkitab, namun menolak penafsiran Alkitab yang tidak proporsional.

Mendiskusikan manifestasi Roh Allah dalam teologi feminis tampaknya dianggap sebagai satu medium yang jitu untuk memperlihatkan kekeliruan dominasi nuansa laki-laki dalam penfasiran Alkitab sekaligus dapat melengkapi konstruksi "wajah" teologi klasik yang merupakan latar historis dari teologi feminis. Karena itu kajian mengenai Roh, termasuk di dalamnya Allah sebagai Wisdom dan Sophia, cukup sering muncul dalam tulisan mengenai teologi feminis. ${ }^{24}$ Pembahasan terhadap tema ini terkait dengan sebuah ironi dimana pada satu sisi manifestasi Allah sebagai Roh dalam Alkitab, utamanya Perjanjian Lama (PL), begitu dominan namun pada sisi lain tradisi kekristenan klasik justru kurang memberi perhatian atau bahkan mengabaikan hakikat Allah yang adalah Roh adanya. Beberapa kutipan pernyataan di bawah ini mengisyaratkan hal tersebut. Fiorenza misalnya menyatakan, "Moreover, ... early Christian tradition of Wisdom-Sophia, which has been almost completely erased from the memory of Western Christianity." 25 Pada bagian lain Fiorenza kembali menyatakan, "When one moves from Jewish Wisdom literature to early Christian writings the figure of Divine Wisdom seems disappear." ${ }^{26}$ Pada bagian lain Fiorenza kembali mengulang gagasan tersebut,

As we have seen, in contrast in Jewish and Gnostic Wisdom literature only a very view direct traces of Divine Wisdom are found in Christian canonical writings. This explains why the early Christian imagination of Israel's G*d within the Gestalt of the G*ddess as Divine Sophia is almost completely lost and forgotten in the self-understanding of the Western Church. ${ }^{27}$

Kesimpulan yang lebih halus dari pengabaian di atas bisa dilihat dalam tulisan Johnson,

What then has gone wrong? For despite the pervasiveness of dialectic experience of Spirit, theological articulation about Spirit has traditionally lagged considerably behind reflection on God unoriginate source of all and God incarnate, classically named Father and Son respectively. The history of doctrine shows that the Spirit, while the first and most intimate way God is experienced, was yet the last to be named explicitly divine. ${ }^{28}$

\footnotetext{
23 Ibid., 92.

${ }^{24}$ Baca misalnya Johnson, She Who Is, 124-149; Elisabeth Schüssler Fiorenza, Jesus: Miriam's Child, Sophia's Prophet - Critical Issues in Feminist Christology (New York: Continuum, 1995), 131-162; Clifford, Memperkenalkan Teologi Feminis, 177-185; Elizabeth A. Johnson, "Naming God She, The Theological Implication"

https://repository.upenn.edu/cgi/viewcontent.cgi?referer=https://www.google.co.id/\&httpsredir=1\&article=1004 \&context=boardman\&a=bi\&pagenumber $=1 \& \mathrm{w}=100$ dalam (diakses 2 Juli 2020).

${ }^{25}$ Fiorenza, Jesus: Miriam's Child, 131.

${ }^{26}$ Ibid., 139.

27 Ibid., 155.

${ }^{28}$ Johnson, She Who Is, 128.
} 
Menurut Johnson dari formulasi urutan penyebutan Allah Tritunggal saja, baik yang diucapkan secara lisan di gereja maupun yang tersurat dalam berbagai dokumen atau kredo gereja, telah memperlihatkan jejak-jejak pengabaian itu. Roh Allah yang manifestasinya paling menonjol dalam Alkitab justru diletakkan pada posisi ketiga setelah Bapa dan Putera. Inilah yang saya identifikasi sebagai ironi di atas.

Teolog feminis umumnya melihat realitas ini efek dari kultur androsentris dan paternalistik dari teologi klasik. Kultur gereja klasik lebih menyukai gagasan Allah yang hierarkis dan transendental. Penyelidikan Alkitab secara cermat akan menggiring kepada kesimpulan bahwa rupanya Roh adalah hakikat Allah yang paling dekat dengan dunia ciptaan. Beberapa kalimat Johnson misalnya mengkonfirmasi hal ini, al.: "The Spirit is the living God present throughout the world and struggle of human history," 29 "..., Spirit-Sophia is the living God at her closest to the world, ..."30 Roh adalah manifestasi kehadiran Allah yang imanen bukan transenden. Dalam kaitannya dengan isu ini, ketika mengulas tentang biblical imagery, Frye berpendapat bahwa konsep transendental memang secara luas diasosiasikan dengan $a$ masculine deity, sementara yang imanen dengan a maternal one. ${ }^{31}$

Secara eksplisit Johnson mengaitkan pengabaian Roh dengan kultur transendental gereja klasik ini dengan menyatakan, "Perhaps, especially in the West, the neglect is due to the nature of the thought systems that emphasize divine transcendence in a less than relational way." ${ }^{32}$ Bahkan pada bagian awal bukunya Johnson langsung menyatakan hal yang senada dengan yang di atas namun secara lebih tegas, "Classical theism emphasizes in a one-sided way the absolute transcendence of God over the world, God's untouchability by human history and suffering, and the all-pervasiveness of God's dominating power to which human beings owe submission and awe". ${ }^{33}$ Johnson menggambarkan potret Allah dalam teologi klasik ini mengikuti sebuah model "an earthly absolute monarch"34 yang patriarkat dan hierarkis. Sebagai seorang Raja dalam sebuah model monarki yang absolut, Allah diposisikan sebagai seorang Raja yang duduk di tahta singgasana dalam istana-Nya yang megah serta dikelilingi oleh sejumlah pengawal yang gagah perkasa. Potret semacam inilah yang digambarkan serta yang disukai dan diproklamasikan dalam teologi klasik. Teologi klasik semacam ini tidak saja dianggap gagal untuk membebaskan kaum perempuan namun justru melanggengkan diskriminasi atau penindasan bagi kaum perempuan. Inilah salah satu konstruksi sosial yang memunculkan teologi "pembebasan” feminis.

\footnotetext{
${ }^{29}$ Ibid., 146.

${ }^{30}$ Ibid., 147.

${ }^{31}$ Northrop Frye, The Great Code: The Bible and Literature (New York: Houghton Mifflin Harcourt Publishing, 1982), 69.

${ }^{32}$ Johnson, She Who Is, 128.

${ }^{33}$ Ibid., 21.

${ }^{34}$ Ibid., 20.
} 


\section{Latar Historis Teologi Proper Injil Matius}

Penggunaan sebutan Bapa kepada Allah dalam injil ini sangat unik. Dari sisi frekuensi kemunculannya, sebutan ini jauh melebihi kemunculannya dalam dua injil Sinoptik yang lain, Perjanjian Lama (PL), dan literatur Yudaisme Bait Allah Kedua (YBAK). Tidak hanya dari sisi frekuensi, konteks serta motif penggunaannya dalam injil Matius pun berbeda dengan yang ada dalam PL dan literatur YBAK. ${ }^{35}$ Mengingat baik penulis serta pembaca pertama injil ini adalah komunitas Yahudi, keunikan tersebut menjadi medium yang sangat penting untuk menemukan teologi proper injil ini.

Tubuh YBAK terdiri atas kelompok atau sekte yang jumlahnya belum bisa dipastikan. ${ }^{36}$ Karena realitas ini maka perdebatan bahkan pertarungan antarkelompok dalam YBAK pun kerapkali tidak terhindarkan. Dalam pertarungan tersebut isu mengenai pemahaman tentang Allah menjadi polemik utama. ${ }^{37}$ Dengan kesimpulan ini, pemahaman tentang Allah atau teologi proper menjadi isu perdebatan atau "pertarungan" di antara kelompok atau sekte dalam YBAK hingga era Formative Judaism. Allah sebagai Bapa dalam injil Matius ini merupakan "senjata" Matius dalam perdebatan tersebut.

Yang akan ditelusuri kemudian adalah bagaimana Allah pada umumnya dipahami dalam YBAK atau setidaknya dalam Yudaisme abad pertama Z.B. Dengan menemukannya diharapkan akan menemukan latar historis teologi proper injil Matius. Saya akan menggunakan metafora kesaksian dalam ruang pengadilan yang diusulkan oleh Brueggemann yang menyatakan, "The court, however, has no access to the 'actual event' beside the testimony. It cannot go behind the testimony to the event, but must take the testimony as the 'real portrayal'."38 Kesaksian pertama adalah dari Injil Matius sendiri, namun untuk menghindari kesaksian yang berat sebelah, walau kesaksian injil juga dipakai secara luas bahkan oleh penulis Yahudi sendiri, ${ }^{39}$ saya juga akan menelusuri sejumlah kesaksian dalam

\footnotetext{
${ }^{35}$ Untuk melihat keunikan penggunaan sebutan Bapa bagi Allah dalam injil Matius bila dibandingkan dengan PL maupun dengan sejumlah literatur YBAK baca Pelita H. Surbakti, Yang Terutama dalam Amanat Agung: Sebuah Pencarian Makna Kata Têrein dalam Matius 28:20a (Jakarta: BPK, 2017), 52-58.

36 "Although we cannot be sure of the exact number, there can be no doubt that at the time of the destruction of the Temple in 70 A.D., the Jewish community comprised numerous parties, sects and brotherhoods. Recent scholarship has questioned and effectively destroyed the concept of a monolithic "Judaism" that existed during the Second Temple (516 B.C. - 70 A.D.). Furthermore, Josephus' famous listing of the standard divisions - Pharisees, Sadducees, Essenes, and the "Fourth Philosophy" (the Zealots) — is simply not adequate in conveying the mosaic of Second Temple Judaism." William C. Varner, Jesus and Pharisees: A Jewish Perpective (Missouri: Personal Freedom Outreach,1996), 1.

37 "The core belief of first-century Judaism gave rise to debates over how God would act to redeem and save his people." David Wenham and Steve Walton, Exploring the New Testament Vol. 1 (London: SPCK, 2001), 37; "The inquiry at hand centers on symbols through which Jews expressed their feeling for God, their view of God's rule of the world ..." Jacob Neusner, "Varieties of Judaism in the Formative Age," dalam Arthur Green (ed.), Jewish Spirituality: From the Bible through the Middle Ages (New York: Crossroad, 1986), 176; Surbakti, "Menghidupkan Leluhur", 5.

${ }^{38}$ Walter Brueggemann, Theology of the Old Testament: Testimony, Dispute, Advocacy (Minneapolis: Fortress Press, 1997), 121.

39 "The dominant trait of Pharisaism before 70 as depictes both in the rabbinic traditions about the Pharisees and in the Gospels, ..." Nuesner, "Varieties of Judaism," 191.
} 
literatur YBAK termasuk pendapat para ahli, termasuk dari kalangan Yahudi, mengenai praktik religiositas orang Yahudi pascakehancuran baik Allah.

\section{Kesaksian dari Injil Matius}

Kesaksian ini terdiri atas dua bagian yakni teks Injil Matius sendiri dan yang kedua adalah latar sejarah kitab Injil Matius. Dari sisi teks Injil Matius, saya akan mulai dengan tema yang membingkai injil Matius yaitu "Allah Bersama Kita." Matius 1:23 dan Matius 28:20 merupakan sebuah inklusio. ${ }^{40}$ Artinya seluruh retorika injil ini ditujukan untuk meyakinkan setiap pembaca bahwa Allah bersama mereka dalam diri Yesus Kristus. Yesus tidak saja disajikan sebagai Imanuel (Mat. 1:23) namun juga disajikan sebagai orang Nazaret (Mat. 2:23). Nazaret bukanlah kota yang penting pada masa itu, ia adalah sebuah kota yang terabaikan dan berisi penduduk miskin dengan berbagai krisis. Hal ini dapat dilihat dari ketidakpercayaan masyarakat Palestina, termasuk murid Yesus sendiri, terhadap pemberitaan bahwa Mesias akan datang dari Nazaret, "Kata Natanael kepadanya: Mungkinkah sesuatu yang baik datang dari Nazaret?" (Yoh. 1:46). Nazaret juga disebut sebagai "place of insignificant". ${ }^{41}$ Dengan atribut ini, dari sejak awal injil Matius hendak menegaskan bahwa Yesus Matius - Sang Allah Bersama Manusia - adalah pribadi yang sangat memahami pergumulan pembaca-Nya sebab Dia juga mengalami apa yang mereka alami. ${ }^{42}$

Selanjutnya dengan mengamati berbagai tulisan yang berupaya memotret "wajah" Yesus Matius Sang Imanuel ini, banyak yang menyimpulkan bahwa wajah kemanusiaan Yesus jauh lebih ditekankan daripada wajah keallahan-Nya. Dimensi horizontal Yesus Matius jauh lebih ditekankan daripada dimensi vertikal-Nya, atau setidaknya dimensi horizontal Yesus Matius berperan sebagai penyempurna potret Yesus yang juga memiliki dimensi vertikal. ${ }^{43}$ Hal ini karena yang menjadi penekanan Matius adalah gagasan Allah bersama manusia atau Allah berdiam dekat dengan manusia. Upaya untuk mengusung gagasan tersebut tampak jelas dalam kisah kematian Yesus yang disajikan bersamaan dengan terbelahnya tirai Bait Allah yang selama ini menjadi pemisah sakral antara Allah dan manusia. ${ }^{44}$ Melalui peristiwa ini Matius hendak memberi pesan kepada pembacanya bahwa dalam Yesus Matius,

${ }^{40}$ Beberapa di antaranya Maarten. J. J. Menken, Matthew's Bible: The Old Testament Text of the Evangelist (Leuven: Leuven University Press, 2004), 129; Leon Morris, The Gospel According to Matthew (Grand Rapids: Eerdmans, 1992), 31; Craig S. Kneeer, Matthew (Leicester: IVP, 1997), 64; John Nolland, The Gospel of Matthew (Grand Rapids: Eerdmans, 2005), 101-102; Pelita Hati Surbakti, "Menghidupkan Leluhur: Sebuah Penafsiran Terhadap Matius 22:32" Gema Teologika, Vol. 4. No. 1 (April 2019), 2.

${ }^{41}$ Matt Woodley, The Gospel of Matthew: God with Us (Downers Grove: IVP, 2011), 38.

42 "Jesus the Nazarene implied 'Jesus, the Lowly Nobody'." Woodley, The Gospel of Matthew, 38.

43 Baca Richard Beaton, Isaiah's Christ in Matthew's Gospel (Cambridge: CUP, 2002), 175-176. Beberapa ahli yang sepakat dengan kesimpulan ini yang dikutip oleh Beaton adalah: Gerhardsson, Hill, Schnackenburg, dan Luz.

44 Donald A. Hagner, Matthew 14-28, WBC (Nashville: Thomas Nelson , 1995), 849._Terhadap peristiwa terbelahnya tirai tersebut Hagner misalnya menyatakan, “... making available to all people a new, bold, unrestricted access in to God's very present." 
Allah kini dapat ditemui oleh siapa saja secara langsung (bukan hanya melalui para imam dengan sejumlah ritual tertentu) dan kapan saja (bukan hanya pada hari-hari tertentu).

Selanjutnya latar sejarah kitab akan dimulai dengan menelusuri latar sosial pembaca pertama Injil. Kitab ini ditulis kepada jemaat yang sedang mengalami krisis identitas sekitar 85 Z.B. Krisis ini berawal dari kehancuran Yerusalem tahun 70 Z.B., tepatnya setelah persidangan di Yamnia, yang melahirkan sebuah gerakan konsolidasi dalam tubuh YBAK atau yang sering disebut sebagai Formative Judaism. ${ }^{45}$ Salah satu konsekuensi dari konsolidasi ini adalah Yudaisme menyikapi dengan tegas dan keras semua kelompok atau sekte dalam tubuh YBAK yang selama ini sama-sama berada dalam Sinagoge. Mereka yang dianggap menyimpang didorong untuk segera keluar dari Sinagoge. Komunitas Matius yang merupakan pembaca pertama Injil ini termasuk ke dalam kelompok dalam Yudaisme yang dianggap telah menyimpang tersebut. Terlepas dari perdebatan apakah pada saat penulisan injil ini mereka telah keluar dari Sinagoge atau belum, peristiwa ini tentu menambah penderitaan mereka. Bisa dibayangkan bahwa belum begitu lama mereka mengalami "pembasmian" secara sistematis oleh imperium Romawi yang juga telah menghancurkan kota Yerusalem dan terutama Bait Allah, ${ }^{46}$ kini mereka juga hendak diusir dari Sinagoge bukan oleh bangsa Romawi namun oleh bangsa mereka sendiri yakni sekelompok pemimpin agama dalam YBAK. Karena itulah para ahli melihat penderitaan mereka terutama bukanlah penderitaan fisik, namun terutama adalah sebuah pergulatan identitas. Apakah dengan mengikuti Yesus, dan menolak kepemimpinan tradisional, terutama Farisi, mereka masih berada dalam karya dan janji penyelamatan Yahwe? Karena itu pula potret Yesus dalam injil ini secara dominan disajikan sebagai kegenapan nubuatan dalam kitab suci mereka (Tanakh). ${ }^{47}$ Dengan demikian tidak mengherankan bila Harrington menyebut injil ini sebagai injil pastoral. Harrington menyimpulkan bahwa injil ini ditulis kepada komunitas yang sedang berada dalam situasi krisis. ${ }^{48}$ Dengan kesimpulan ini semakin memperlihatkan bahwa gagasan imanensi Allah memang sangat kuat dalam injil ini, dan tentu saja sangat dekat dengan tema "Allah bersama manusia" di atas.

Lalu apa kaitan potret Allah yang dekat atau Allah bersama manusia yang dipropagandakan secara masif dan sistematis dalam injil ini dengan pemahaman umum tentang Allah dalam YBAK? Cukup banyak ahli menyimpulkan bahwa injil merupakan sebuah tulisan yang ditujukan untuk merespons situasi para pembacanya. Bila injil Matius

45 "It (Formative Judaism) refers to the reorganization and consolidation of Judaism in the period following the first Jewish war. This attempt to salvage the Jewish faith from disaster of the war and the loss of the temple was undertaken by a coalition of forces." David C. Sim, The Gospel of Matthew and Christian Judaism (Edinburgh: T\&T Clark, 1998), 113.

${ }^{46}$ Baca Donald Senior, What are they Saying about Matthew? (New York: Paulist Press, 1996), 8. Donald Senior menyebut peristiwa perang Yahudi tersebut sebagai holocaust.

${ }^{47}$ Kutipan-kutipan PL dalam Injil Matius jauh lebih banyak bila dibandingkan dengan Injil lain, dan semua kutipan itu hendak menunjukkan bahwa Yesus telah menggenapi kitab suci.

48 Lihat Daniel J. Harrington, "Matthew's Gospel: Pastoral Problems and Possibilities," dalam The Gospel of Matthew in Current Study, peny. David E. Aune (Grand Rapids: Eerdmans, 2001), 62-63. 
mengajarkan Allah yang dekat, maka Allah yang jauh dan begitu formal telah diajarkan dalam YBAK dan dipraktikkan secara luas. Setidaknya ada kelompok dalam YBAK yang mengajarkan Allah yang jauh dan berelasi dengan begitu formal dengan manusia. Selanjuntnya akan diperlihatkan realitas pemahaman tentang Allah yang transenden dalam sejumlah literaur YBAK.

\section{Kesaksian dari Literatur YBAK}

Dalam bagian ini saya mulai dengan menelusuri gambaran Allah dalam 3 Henokh. Dalam pengantar kitab 3 Henokh misalnya, P. Alexander menyajikan tiga cara 3 Henokh menggambarkan Allah yang transenden itu yakni, "1. God is said to be spatially remote from man. 2. God is represented as being well-high inaccessible to man; 3. God's transcendence is expressed through the story in 3 Enoch 5:10-14 of the withdrawal of his Sekinah from the earth." ${ }^{\prime 4}$ Ketiga potret di atas merupakan hakikat Allah Israel yang dipahami pada waktu itu. Dengan mengamati beberapa literatur YBAK, termasuk 2 Henokh dan 3 Henokh, Bauckham bahkan memandang takhta sorgawi Allah (the heavenly throne of God) ini sebagai keunikan monoteisme YBAK. Gambaran Allah semacam ini menurut Bauckham mendominasi konstruksi teologi proper pada era $\mathrm{YBAK}^{50}$ Dengan menelusuri tulisan-tulisan pada era YBAK, dan juga PL, Lester L. Grabbe juga menyimpulkan hal yang senada dengan Bauckham. ${ }^{51}$

Dalam kitab 2 Henokh misalnya, gambaran Allah yang sangat suci, agung, dan mulia itu juga ditampilkan. Dalam 2 Henokh 22:1-4 diperlihatkan perjalanan Henokh ke Surga dan menyaksikan hadirat Allah yang penuh dengan makhluk surgawi lengkap dengan takhta-Nya yang sangat megah. Keagungan dan kemuliaan ini membuat Henokh jatuh tersungkur dalam sikap hormat, "And I fell down flat and did obeisance to the Lord" (22:4-5). Gambaran posisi Allah Israel yang sedemikian rupa pada satu sisi telah menempatkan-Nya pada posisi yang sangat suci, agung, dan cenderung menjadi sangat berjarak dengan manusia. Ia diposisikan layaknya seorang Raja di dalam takhta surgawi-Nya, bukan di dunia, yang megah dan dikelilingi oleh makhluk-makhluk khusus. Hal ini membuat tidak sembarang orang dan tidak setiap saat bisa menemui-Nya.

49 P. Alexander, "3 (Hebrew Apocalypse of) Enoch: A New Translation and Introduction," dalam The Old Testament Pseudepigrapha vol 1, peny. Jamesh H. Charlesworth (Peabody-: Hendrickson, 2009), 241.

50 "In second Temple Judaism, then, the throne of God in the highest heaven became a key symbol of monotheism, representative of one of the essential characteristics definitive of divine identity ... The uniqueness of the heavenly throne of God belongs to the logic of the monotheism that dominated common Judaism in the Second Temple period." Richard Bauckham, "The Throne of God and the Worship of Jesus," dalam Carey C. Newman, Jamesh R. Davila, Gladys S. Lewis (eds.), The Jewish Roots of Christological Monotheism (Leiden: Brill, 1999), 53.

51 "Monotheism in antiquity and the present has not denied the existence of other heavenly beings or a developed spirit world. What it dinies is that these spirits are in any way equal to or comparable to God ... God is assisted by various angelic figures (some are labeled "archangels"), and there seem to be other angels who form the celestial bodies or carry out different and often specialized task. Although heavenly beings, these angels are completely different and subordinate to God himself." Lester L. Grabbe, Judaic Religion in The Second Temple Period: Belief and Practice from The Exile To Yavneh (London: Rudledge, 2000), 230. 
Medium yang digunakan oleh Bauckham untuk mendukung kesimpulannya di atas adalah dengan mengamati gelar "Most Hight" yang ternyata cukup populer dalam religiositas Yahudi pada era YBAK. Secara khusus dalam bab tiga bukunya tersebut, ${ }^{52}$ yang telah di kutip di atas, Bauckham memperlihatkan bahwa gelar "Most High" ini cukup populer dalam religiositas Yahudi pada periode 250 B.C.E.-150 Z.B.. Pada bagian akhir bab tiga tersebut Bauckham bahkan menyajikan tabel yang memperlihatkan sejumlah pemakaian gelar "Most High" dalam literatur Yahudi. ${ }^{53}$ Menurutnya ada 284 kali penggunaan gelar tersebut. Pemberian gelar tersebut bukan saja hendak memosisikan Allah Israel sebagai penguasa segenap alam, namun juga yang paling tinggi dalam apa yang sering disebut the heavenly throne of God. Bauckham menyimpulkan penggunaan gelar ini dengan menyatakan, "Clearly, the title came into much more general use in the later Second Temple period than had been the case previously." 54 Grabbe juga menyimpulkan bahwa penggunaan gelar yang memosisikan Allah Israel pada tempat yang sangat tinggi memang semakin populer dalam YBAK. ${ }^{55}$ Kesimpulan yang senada juga muncul dalam kalimat Hurtado ketika merespons $\mathrm{H}$. P. Nillson mengenai monoteisme YBAK. ${ }^{56}$ Dengan demikian monoteisme YBAK bukanlah strict monotheism - atau ada juga yang menyebutnya exclusive monotheism ${ }^{57}$ - yakni monoteisme yang menyangkal adanya pribadi ilahi lain yang berada bersama-sama dengan Allah Israel. Fakta bahwa dalam berbagai literatur YBAK tampak pribadi ilahi lain selain Allah membuat para ahli menyimpulkan bahwa monotesime YBAK ini semacam monarchy monotheism, yakni pemahaman bahwa selain Allah ada sejumlah makhluk ilahi lainnya yang berada dalam sebuah takhta surgawi yang ilahi. Hal ini sama dengan apa yang disebut sebagai inclusive monotheism (monoteisme inklusif). Namun Bauckham membuat definisi yang sedikit berbeda dengan Mach mengenai monoteisme eksklusif. Bagi Bauckham monoteisme

\footnotetext{
${ }^{52} \mathrm{Bab} 3$ buku tersebut diberi judul "The'Most Hight' God and the Nature of Early Jewish Monotheism," Bauckham, Jesus and the God of Israel, 107-126.

${ }_{53}$ Richard Bauckham, Jesus and the God of Israel: God Crucified and Other Studies on the New Testament's Christology of Divine Identity (Grand Rapids: Eerdmans, 2009), 123-126.

${ }^{54}$ Ibid., 110.

55 "In the Second Temple period, the name Yhwh came to be used less and less. It was replaced by more generic titles such as "God of Heaven" (mainly a Persian-period usage but probably not a Persian creation; see DDD2: 370-72) and Adonai, "Lord." A number of what were originally separate deities had become assimilated to Yhwh in pre-exilic times. With the translation of the Bible into Greek, these divine names were translated as if they were titles (e.g. Shaddai became hikanos "(all) sufficient," pantokrator "almighty"; Elyon, hupselos, hupsistos "most high")." Grabbe, Judaic Religion in The Second Temple Period, 216.

56 "I propose that Jewish monotheism can be taken as constituting a distinctive version of the commonly-attested belief structure described by Nilsson as involving a "high god" who presides over other deities. The God of Israel presides over a court of heavenly beings who are likened to him (as is reflected in, e.g., the OT term for them "sons of God"). ... In Greco-Roman Jewish belief, however, the high god is known as the God of Israel, whose ways and nature are revealed in the Scriptures of Israel. Also, as the evidence of Jewish prayer and cultic practice surveyed above shows, Jews characteristically expected, indeed felt obliged, to address their high God directly in prayer and worship." Larry W. Hurtado, "What Do We Mean by "First Century Monotheism'?," Society of Biblical Literature Seminar Papers/SBLSP 32, peny. Eugene H. Lovering (Atlanta: Scholars, 1993), 348-368.

57 Baca misalnya Michael Mach, "Concepts of Jewish Monotheism During the Hellenistic Period," dalam Carey C. Newman, Jamesh R. Davila, Gladys S. Lewis (eds.), The Jewish Roots of Christological Monotheism (Leiden: Brill, 1999), 24.
} 
eksklusif adalah monoteisme yang tidak menyangkal adanya makhluk-makhluk ilahi lainnya, namun mereka bukanlah Allah tetapi hanyalah ciptaan dari Allah. ${ }^{58}$ Sementara monoteisme inklusif menurut Bauckham adalah monoteisme yang memahami bahwa Allah Israel adalah Allah yang paling tinggi dan terkuat dari allah-allah yang disembah oleh bangsa-bangsa lain. ${ }^{59}$ Ia dipercayai sebagai pribadi yang paling tinggi dan paling berkuasa dari semua makhluk ilahi lainnya. ${ }^{60}$

Dengan kesimpulan di atas semakin tampak bahwa monoteisme YBAK menempatkan Allah Israel pada posisi yang sangat tinggi bahkan yang paling tinggi dalam apa yang disebut Hurtado sebagai court of heavenly beings. Bauckham menyebut realitas ini sebagai transcendent uniqueness ${ }^{61}$ dari Allah Israel. Dengan demikian jangankan di alam fisik, di alam metafisik sekalipun Dia diposisikan sangat tinggi dan berbeda jauh dengan makhlukmakhluk ilahi lainnya. ${ }^{62}$ Allah tidak saja digambarkan laksana seorang Raja yang berada di tahta yang dikelilingi oleh pengawal yang kuat tetapi juga memiliki kemuliaan dan kekayaan yang sangat besar. ${ }^{63}$

\section{Kesaksian dari Perspektif Praktik Religiositas}

Dalam bagian ini saya akan menelusuri praktik religiositas orang Yahudi pascakehancuran Bait Allah. Banyak ahli yang menyimpulkan bahwa perang Yahudi, yang diikuti dengan sidang Yamnia, telah membawa perubahan yang sangat besar dalam religiositas YBAK. ${ }^{64}$ Setelah sidang Yamnia, para Rabbi mulai mengidentifikasi seluruh kelompok atau sekte dalam YBAK secara ketat, keras, dan tidak jarang beberapa di antaranya disebut sebagai bidat. Pemberlakuan ketaatan kepada Taurat secara ketat dan keras sebagai pengganti praktik religiositas dalam Bait Allah pun diterapkan. Gerakan Yahudi-Kristen semacam komunitas Matius juga kena imbasnya. Senior mengatakan, "Although prior to events A.D. 70 the Jewish Christians had been part of Jewish liturgical and Synagogue life,

\footnotetext{
${ }^{58}$ Bauckham, "The Throne of God and the Worship of Jesus," 109.

${ }^{59}$ Bauckham, "The Throne of God," 108.

${ }^{60}$ Bauckham, Jesus and the God of Israel, 108, 109, 111.

${ }^{61}$ Ibid., 109.
}

62 "Imagery of hight is pervasive in early Jewish picturing of God. It pictures God's transcendent supremacy over all things, in heaven or on earth. The very 'lofty' throne of God is situated in the highest of the heavens, or even 'above the heavens', far above all the many ranks of angels that worship and serve him. It represents the absolute sovereignty of God over the whole cosmos. It coheres with one of the essential aspects of the uniqueness of the one God that are repeated everywhere in early Jewish literature: that God is the only sovereign Ruler over all things, while all beings other than God are his creatures, subject to his will. Sometimes this idea of God's unlimited sovereignty is explicitly expressed in the context of use of the title 'the Most High'." Bauckham, Jesus and the God of Israel, 119-120.

${ }^{63}$ Gambaran Allah dan takhta-Nya dapat di lihat dalam D.S. Russel, Penyingkapan Ilahi, terj. Iaones Rakhmat (Jakarta: BPK, 1993), 113-115.

${ }^{64}$ Salah satu uraian yang cukup menarik mengenai peristiwa tahun 70 Z.B. ini baca Bas ter Haar Romeny, "Hypotheses on the Development of Judaism and Christianity in Syria in the Period after 70 C.E." dalam Huub van de Sandt (ed.), Matthew and the Didache (Assen-Minneapolis: Royal Van Gorcum-Fortress Press, 2005), 15-18. 
that was no longer possible in the atmosphere of strict identity set up by Yamnia." ${ }^{\circ 5}$ Pelaksanaan Taurat yang keras dan sangat literer bahkan cenderung berlebihan pascakehancuran Bait Allah ini diakui teolog Yahudi seperti Rabbi Jacob Neusner. ${ }^{66}$ Terhadap berbagai ritual yang ditekankan oleh kelompok Farisi, Neusner menyatakan, "The dominant trait of Pharisaism before 70 as depictes both in the rabbinic traditions about the Pharisees and in the Gospels ${ }^{67}$, was concern for certain matters of rite." ${ }^{968}$ Bahkan setelah kehancuran Bait Allah, berbagai ritual dan hukum kesucian masih menjadi penekanan, dan Farisi memosisikan diri mereka dalam posisi imam Bait Allah. ${ }^{69}$ Memang Farisi bukanlah satu-satunya kelompok dalam YBAK, namun kelompok ini menjadi sangat dominan dalam Yudaisme setelah kehancuran Bait Allah tahun 70 C.E. ${ }^{70}$ Sebagai kelompok yang merasa bertanggungjawab atas posisi imam, hukum-hukum kesucian tidak lagi diberlakukan hanya dalam Bait Allah namun juga di luar Bait Allah. ${ }^{71}$ Penerapan hukum kesucian yang sangat keras tersebut tampaknya tidak terlepas dari bagaimana kelompok Farisi memosisikan Allah yang memang sangat suci dan agung sehingga manusia harus melakukan ritual kesucian tertentu bila hendak "bertemu" dengan Dia. Sikap ini tidak terlepas dari pengaruh peristiwa Yamnia. Namun apa pun alasannya, salah satu konsekuensi dari penerapan Taurat yang keras ini membuat Allah menjadi sangat formal dan relatif berada dalam posisi yang semakin jauh dari manusia. Penerapan Taurat yang keras pada sisi tertentu telah membuat Taurat tidak lagi hadir sebagaimana mestinya. Indikasi ini terlihat misalnya dalam kutipan kalimat Yesus dalam Matius 23:23 “...tetapi yang terpenting dalam hukum Taurat kamu abaikan, yaitu: keadilan dan belas kasihan dan kesetiaan ..." Bahkan Taurat telah menjadi kuk yang memberatkan.

Marilah kepada-Ku, semua yang letih lesu dan berbeban berat, Aku akan memberi kelegaan kepadamu. Pikullah kuk yang Kupasang dan belajarlah pada-Ku, karena Aku lemah lembut dan rendah hati dan jiwamu akan mendapat ketenangan. Sebab kuk yang Kupasang itu enak dan beban-Kupun ringan. (Mat. 11:28-30).

${ }^{65}$ Senior, C. P, What Are They Saying, 9.

${ }^{66}$ Neusner, "Varieties of Judaism," 170-197.

${ }^{67}$ Menarik sekali bahwa penggalan kalimat Neusner ini sekaligus mengkonfirmasi bahwa kesaksian dari Injil Matius di atas memang layak digunakan untuk merekonstruksi potret Allah dalam YBAK.

${ }^{68}$ Nuesner, "Varieties of Judaism," 191.

69 "This Pharisaic attitude would be highly appropriate to the time when the Temple no longer stood. The Pharisees had already entered that time, in a strange and paradoxical way, by pretending to be the Temple priests." Neusner, "Varieties of Judaism," 192.

${ }^{70}$ Hal ini karena kelompok ini bukanlah gerakan politik yang menjadi ancaman bagi Romawi seperti Zelot, dan bukan pula kelompok yang memilih untuk mengundurkan diri dari ruang-ruang publik seperti kelompok Eseni.

71 "To be sure, everyone who went to the Temple had to be ritually pure. But outside the Temple the laws of ritual purity were not widely observed ... But the Pharisees held, on the contrary, that even outside of the Temple, in one's own home, one had to follow the laws of ritual purity ..." Nuesner, "Varieties of Judaism," 191. 
Setelah menelusuri pemahaman tentang Allah dari perspektif praktik ritual, posisi Allah yang jauh ini juga sangat mungkin telah dipahami secara luas dan berdampak kepada sejumlah praktik religiositas dalam YBAK.

Dengan demikian sebagaimana yang menjadi tujuan bagian ini, kombinasi antara ketiga kesaksian di atas telah menghasilkan kesimpulan sebuah potret Allah yang jauh, sakral, penuh kemuliaan dan kekayaan serta cenderung berinteraksi dengan manusia dalam nuansa yang formal. Inilah latar historis teologi proper injil Matius yang kemudian menyajikan sebuatan Allah sebagai Bapa dengan sangat unik. Teologi proper injil Matius melalui sebutan Bapa kepada Allah hadir untuk merespons pemahaman Allah yang jauh, formal, serta hirarki sebagaimana yang tampak pada era YBAK atau tepatnya Yudaisme abad pertama C.E.

\section{Kesimpulan}

Setelah melakukan studi komparatif terhadap teologi proper Injil Matius dan teologi Feminis, ada beberapa kesimpulan yang diperoleh.

1. Penyebutan Allah sebagai Bapa tidak sejalan dengan makna penyebutan Bapa dalam pandangan beberapa teolog Feminis yang telah disinggung di atas. Bisa jadi pemaknaan terhadap kata "bapa" semacam itu lebih dipengaruhi oleh pengalaman empiris atau pengalaman nyata dari beberapa perempuan di beberapa tempat, namun pemaknaan yang mengandung gagasan penindasan dan diskriminasi semacam itu tidak sesuai dengan "Bapa" yang diajarkan oleh Yesus dalam Injil Matius.

2. Berdasarkan penelitian di atas, latar sejarah teologi Proper Injil Matius, yang memproklamasikan Allah sebagai Bapa, dan latar sejarah teologi feminis memiliki kesamaan yang sangat fundamental. Keduanya lahir dari sebuah pertarungan internal sebuah agama. Yudaisme Bait Allah Kedua, tepatnya Formative Judaism, untuk Injil Matius, dan Teologi Klasik Barat untuk teologi Feminis. Keduanya sedang melawan teologi proper yang hirarki, diskriminatif, dan yang bisa saja mengarah kepada penindasan pada zamannya masing-masing. Dalam pertarungan tersebut, baik Injil Matius maupun teologi Feminis sama-sama melawan konstruksi teologi proper yang sama yakni potret Allah yang terlalu jauh dengan manusia. Potret Allah yang transenden dan hierarkis secara tidak proporsiaonal menjadi latar sejarah keduanya. Keduanya justru bermotif pembelaan bagi mereka yang tertindas dan terbelenggu. Situasi ini membuat dimensi Allah yang imanen menjadi "senjata utama" dalam pertarugan dengan lawan mereka masing-masing. Bila imanensi Allah oleh teologi feminisme dikemukakan melalui ide Allah sebagai Roh yang sangat memang dominan dalam Alkitab, maka imanensi Allah dalam Injil Matius ditekankan melalui Allah sebagai Bapa.

3. Setidaknya dengan kesimpulan-kesimpulan di atas, penyebutan Allah sebagai Ibu yang diusulkan oleh sebagain teolog feminis seharusnya tidak lagi lahir dari asumsi yang menilai bahwa gagasan sebutan Bapa dalam Alkitab adalah budaya androsentris yang 
diskriminatif dan bahkan melanggengkan penindasan. Sebutan Bapa dan/atau Ibu kepada Allah sama-sama memungkinkan.

4. Yang harus kita ingat adalah, baik sebutan Bapa ataupun Ibu bagi Allah sama-sama hanyalah sebuah metafora mengenai Allah. ${ }^{72}$ Walaupun kepenuhan citra Allah ada dalam diri laki-laki (Bapa) maupun dalam diri perempuan (Ibu), namun Allah bukanlah laki-laki dan bukan pula perempuan. Semua kata ataupun frasa yang dipakai oleh Manusia untuk merujuk kepada Allah tidaklah sanggup untuk menampung secara paripurna hakikat Allah yang sesungguhnya. Bahkan kata "Allah" pun tidak!

\section{Daftar Pustaka}

Alexander, P. "3 (Hebrew Apocalypse of) Enoch: A New Translation and Introduction," dalam Jamesh H. Charlesworth (ed.), The Old Testament Pseudepigrapha vol 1. Peabody-Massachusetts: Hendrickson Publisher, 2009.

Barth, Karl. The Christian Life: Church Dogmatics Vol. IV, part 4. Grand Rapids: Eerdmans, 1981.

Bauckham, Richard. "The Throne of God and The Worship of Jesus," dalam Carey C. Newman, Jamesh R. Davila, Gladys S (eds.), The Jewish Roots of Christological Monotheism. Lewis. Leiden: Brill, 1999. . Jesus and the God of Israel: God Crucified and Other Studies on the New Testament's Christology of Divine Identity. Grand Rapids: Eerdmans, 2009.

Beaton, Richard. Isaiah's Christ in Matthew's Gospel. Cambridge: CUP, 2002.

Brueggemann, Walter. Theology of the Old Testament: Testimony, Dispute, Advocacy. Minneapolis: Fortress Press, 1997.

Clifford, Anne M. Memperkenalkan Teologi Feminis, terj. Yosef M. Florisan. Maumere: Penerbit Ledalero, 2002.

Dahl, Nils A. "The Neglected Factor in New Testament Theology," dalam Donald H. Juel (ed.), Jesus the Christ: The Historical Origins of Christological Doctrine. Minneapolis: Fortress, 1991.

Daly, Mary. Beyond God the Father: Toward a Philosophy of Women's Liberation. Boston: Beacon, 1974.

Fiorenza, Elisabeth Schüssler. Jesus: Miriam's Child, Sophia's Prophet - Critical Issues in Feminist Christology. New York: Continuum, 1995.

Grabbe, Lester L. Judaic Religion in The Second Temple Period: Belief and Practice from The Exile To Yavneh. London: Rudledge, 2000.

Hagner, Donald A. Matthew 14-28. WBC. Nashville: Thomas Nelson, 1995.

\footnotetext{
72 Baca Watson, Feminist Theology, 30-31; Fiorenza, Jesus: Miriam's Child, 161.
} 
Harrington, Daniel J. "Matthew's Gospel: Pastoral Problems and Possibilities," dalam David E. Aune (ed.), The Gospel of Matthew in Current Study. Grand Rapids: Eerdmans, 2001.

Hutardo, Larry. "What Do We Mean by 'First Century Monotheism'?," Society of Biblical Literature Seminar Papers/SBLSP 32, Eugene H. Lovering (ed.). Atlanta: Scholars, 1993.

Jeremias, Joachim. The Central Message of the New Testament. New York: Charles Scribner's Sons, 1965.

Johnson, Elizabeth A. She Who Is: The Mystery of God in Feminist Theological Discourse. New York: Crossroad, 1994.

Johnson, Elizabeth A. Kristologi di Mata Kaum Feminis, terj. A. Widyamartaya. Yogyakarta: Kanisius, 2003.

Johnson, Elizabeth A. "Naming God She, The Theological Implication" https://repository.upenn.edu/cgi/viewcontent.cgi?referer=https:/www.google.co.id/\&h ttpsredir $=1 \&$ article $=1004 \&$ context $=$ boardman $\& a=$ bi\&pagenumber $=1 \& \mathrm{w}=100 \quad$ dalam (diakses 2 Juli 2020).

Keck, Leander. "Toward the Renewal of New Testament Chrsistology," NTS 32 (1986): 362377.

Kneeer, Craig S. Matthew. Leicester: IVP, 1997.

Mach, Michael. "Concepts of Jewish Monotheism During the Hellenistic Period," dalam Carey C. Newman, Jamesh R. Davila, Gladys S. Lewis (eds.). The Jewish Roots of Christological Monotheism. Leiden: Brill, 1999.

Menken, Maarten. J. J. Matthew's Bible: The Old Testament Text of the Evangelist. Leuven: Leuven University Press, 2004.

Morris, Leon. The Gospel According to Matthew. Grand Rapids: Eerdmans, 1992.

Neusner, Jacob. "Varieties of Judaism," dalam Arthur Green (ed.), Jewish Spirituality: From the Bible Through the Middle Ages. New York: Crossroad, 1986.

Nolland, John. The Gospel of Matthew. Grand Rapids: Eerdmans, 2005.

Romeny, Bas ter Haar. "Hypotheses on the Development of Judaism and Christianity in Syria in the Period after 70 C.E." dalam Huub van de Sandt (ed.) Matthew and the Didache. Assen-Minneapolis: Royal Van Gorcum-Fortress Press, 2005.

Ruether, Rosemary Radford. Sexism and God Talk: Toward a Feminist Theology. Boston: Beacon, 1983.

Russel, D.S. Penyingkapan Ilahi, terj. Iaones Rakhmat. Jakarta: BPK, 1993.

Senior, C. P., Donald. What Are They Saying About Matthew? New York: Paulist, 1983.

Sim, David C. The Gospel of Matthew and Christian Judaism. Edinburgh: T\&T Clark, 1998.

Surburg, Mark P. "God Our Mother? Biblical and Philosophical Considerations in Feminist God Language", Concordia Theological Quarterly, Vol. 79 (2015), 49-65 
Surbakti, Pelita Hati. Yang Terutama dalam Amanat Agung: Sebuah Pencarian Makna Kata Tērein dalam Matius 28:20a. Jakarta: BPK, 2017.

Surbakti, Pelita Hati. "Menghidupkan Leluhur: Sebuah Penafsiran Terhadap Matius 22:32" Gema Teologika, Vol. 4. No. 1 (April 2019), 1-16.

Thompson, Marianne Meye. The God of the Gospel of John. Grand Rapids: Eerdmans, 2001.

Watson, Natalie K. Feminist Theology. Grand Rapids: Eerdmans, 2003.

Wicks, Henry J. The Doctrine of God in the Jewish Apocryphal and Apocalyptic Literature. New York: KTAV, 1971.

Woodley, Matt. The Gospel of Matthew: God with Us. Downers Grove: IVP, 2011. 